\title{
STUDI INSILICO POTENSI MINYAK ATSIRI DAN EKSTRAK ETANOL DAUN ANNONA MURICATASEBAGAI CALON HERBAL TERSTANDART UNTUK ANALGESIK DAN ANTIINFLAMASI
}

\author{
Reza Hakim, Yoni Rina Bintari, Dini Sri Damayanti \\ Staf Fakultas Kedokteran Universitas Islam Malang \\ rezahakim78@gmail.com
}

\begin{abstract}
Inflammatory reactions give rise to a series of processes and symptoms that can cause pain and damage to nearby cells. Inflammatory reactions are mediated by inflammatory and proinflammatory cytokines. NSAID class (non-steroidal antiinflammatory drug) drugs have been developed to inhibit the inflammatory process by suppressing COX-1 and / or COX-2 enzyme activity. However, this drug can cause gastric mucosal irritation. the ethanol extract of Annona muricata leaf has an analgesic and anti-inflammatory effect ${ }^{[3]}$. The purpose of this research is to know analgesic and antiinflamatory activity from ethanol extract and essential oil of Annona muricata leaf.The method used was the study of in silico by molecular docking of active compounds in ethanol extracts and essential oils to the COX-1, COX-2, phospolipaseA, and TNF-alpha receptor molecules as target molecules. The molecular docking results show that Annona muricata ethanol extract can act as an anti-inflammatory and analgesic, especially through strong bonds between "rutine" compounds with COX-2 receptors with affinity $-10 \mathrm{kcal} /$ mold and "quercetin" with affinity bindings -9.8 kkal.mol, better than dexametason (binding affinity $-9.6 \mathrm{kcal} / \mathrm{mol}$ ).
\end{abstract}

Keywords:Inflamation, COX-1, COX-2, phospolipase-A, TNF-alfa, docking

\section{ABSTRAK}

Reaksi inflamasi menimbulkan serangkaian proses dan gejala yang dapat menyebabkan rasa nyeri dan kerusakan sel disekitarnya. Reaksi inflamasi diperankan mediator inflamasi dan sitokin proinflamai. Obat golongan NSAID (non-steroid antiinflamatory drug) telah dikembangkan untuk menghambat proses inflamasi dengan menekan aktivitas enzim COX-1 dan atau COX-2. Namun obat ini dapat menyebabkan iritasi mukosa lambung. Ektrak etanol daun Annona muricata mempunyai efek analgesik dan antiinflamasi. ${ }^{[3]}$ Tujuan penelitian ini untuk mengetahui bahan aktif yang berperan menimbulkan efek analgesik dan antiinflamasi ektrak etanol dan minyak atsiri daun Annona muricata. Metode yang digunakan adalah studi in silico dengan melakukan molecular docking senyawa-senyawa aktif yang ada dalam ekstrak etanol dan minyak atsiri ke molekul reseptor COX-1, COX-2, phospolipase-A, dan TNF-alfa sebagai molekul target. Hasil molecular docking menujukkan bahwa ekstrak etanol Annona muricata dapat bekerja sebagai antiinflamasi dan analgesic, khususnya melalui ikatan yang kuat antara senyawa "rutin" dengan reseptor COX-2 dengan binding affinity $-10 \mathrm{kkal} / \mathrm{mold}$ dan "quercetin" dengan binding affinity $-9,8 \mathrm{kkal} . \mathrm{mol}$, lebih baik disbanding dexametason (binding affinity $-9.6 \mathrm{kkal} / \mathrm{mol}$ ).

Kata kunci: Inflamasi, COX-1, COX-2, phospolipase-A, TNF-alfa, docking 


\section{PENDAHULUAN}

Daun dan biji Annonamuricata diketahui banyak mengandung bahan aktif acetogenin seperti Cohibin A dan B, Sabdelin, Muricoreacin, Murihexol, Donhexocin, Murihexocin A, B dan C, Annonacin ,Annonacin A, Annohexocin. Pemberian ekstrak etanol daun Annona muricata Linn dosis $200 \mathrm{mg} / \mathrm{kg}$ peroral dapat menurunkan edema subplantar tikus yang diinjeksi caragenan ${ }^{[3]}$. Mekanisme anti iinflamasi diduga melalui penghambatan satu atau beberapa proses signaling intraselluler yang diakibatkan oleh mediator inflamasi.Namun demikian dari penelitian tersebut belum dapat diketahui bahan aktif apa yang berkerja sebagai analgesik atau antiinflamasi.

Beberapa tahun terakhir studi insilico mulai banyak dikembangkan sebagai metode untuk memprediksi kemampuan suatu bahan aktif dalam menimbulkan efek biologis secara komputasional dalam rangka pencairan obat baru. Studi ini dikembangkan dalam rangka menekan biaya dan mengurangi lamanya proses yang dibutuhkan untuk suatu bahan aktif menjadi obat yang dapat dipasarkan ke masyarakat ${ }^{[5]}$. Hasil penelitian industri farmasi di Amerika Serikat menunjukkan bahwa pada tahun 2001 untuk biaya pembuatan obat dari suatu bahan aktif sampai obat dapat dipasarkan oleh sebuah industri farmasi dibutuhkan dana sekitar $\$ 880$ juta dengan kisaran waktu yang dibutuhkan selama kurang lebih 12 tahun. Selain faktor biaya dan lamanya proses, beberapa faktor dapat menyebabkan kegagalan suatu obat untuk dipasarkan seperti rendahnya efektifitas obat, timbulnya efek toksik, dan hambatan dalam proses pemasaran itu sendiri ${ }^{[4]}$.

Salah satu metode insilico yang banyak digunakan adalah molecular docking (interaction networks). Prinsip dari tehnik ini adalah memprediksi kemampuan suatu bahan aktif (ligan) berikatan dengan suatu protein target (misalnya reseptor) untuk membentuk kompleks yang stabil. Beberapa tools dapat digunakan untuk metode molecular docking seperti ArgusDock, DOCK, FRED, eHITS, Auto Dock dan FTDock. Kemampuan suatu ligan berikatan dengan active site dari suatu reseptor selanjutnya dilakukan untuk menilai kekuatan aktivasi atau inhibisi ${ }^{[5]}$.

Berdasarkan fakta tersebut diatas, maka penelitian ini bertujuan untuk memprediksi potensi ekstrak etanol daun Annona muricata sebagai analgesik dan antiinflamasi melalui penghambatan enzim Phospholipase A, COX-1, COX2dan $\mathrm{TNF} \alpha$ secara insilico, penentuan kadar flavonoid, dan kemampuan penghambatan denaturasi protein. Keluaran dari hasil penelitian ini berupa keikutsertaan peneliti sebagai pemakalah dalam seminar nasional yang kedepan akan dapat digunakan untuk pengembangan penelitian selanjutnya secara invitro maupun in vivo terhadap hewan coba. Target jangka panjang dari penelitian ini adalah memberikan landasan ilmiah pemanfaatan daun Annona muricata sebagai herbal terstandart dan aman digunakan oleh masyarakat sebagai analgesik dan antiinflamasi.

\section{METODE PENELITIAN}

Desain penelitian secara laboratorium. Penentuan kandungan bahan aktif daun Sirsak (Annona 
muricata) diambil dari hasil penelitian yang telah dilakukan oleh peneliti sebelumnya. Bahan aktif yang terkandung dalam ekstrak etanol daun sirsak (Annona muricata) antara lain Annomuricin A, Annomuricin B, Annomuricin $\mathrm{C}$, Annomutacin D, Annonacin A, Anonaine, Catechin, Chlorogenic acid, Epicatechin, Gallic acid, Kaempferol, Loliolide, Muricapentocin, Murihexocin, Nicotiflorin, Quercetin, Roseoside, Rutin, Vomifoliol, Xylopine. Adapun bahan aktif yang terkandung dalam minyak atsiri antara lain.

\section{Prosedur Kerja}

Struktur 3D bahan aktif diunduh dari server Pub

Chem(https://pubchem.ncbi.nlm.nih.gov) dengan CID yang telah dicatat. Sedangkan reseptor Phospholipase A, COX-1, COX-2 dan TNF $\alpha$ dan inhibitor reference (Indometasin dan Cortisol) didapatkan dari server protein data bank (http://www.rcsb.org/pdb/home/home.do [7]. Potensi sebagai analgesik dan antiinflamasi, dianalisa menggunakan PASS

Server (http://www.pharmaexpert.ru/passonline/i ndex.php). Prediksi potensi senyawa ditunjukkan dengan score probability activity $(\mathrm{Pa})^{[2] .} \mathrm{Pa}$ yang mendekati angka 1 menunjukkan bahan aktif secara komputasi diprediksi mempunyai potensi sebagai analgesik dan antiinflamasi yang akan memberikan hasil yang sama bila dilakukan uji laboratorium.

Selanjutnya, dilakukan proses molecular docking menggunakan program PyRx (autodock vina) ${ }^{[1]}$. Docking dilakukan secara spesifik dengan compound sebagai ligan dan inhibitor reference dan dipilih binding energi yang memiliki hasil terkecil atau paling negatif karena menunjukkan konformasi kompleks yang paling baik. Hasil docking disimpan dan divisualisasikan menggunakanPyMol ${ }^{[3]}$.Hasil docking kemudian di visualisasikan interaksinya sehingga didapatkan data interaksi antar kedua molekul (Phospholipase A ligan compound, COX-1 ligand compound, Cox-2 ligand compound atau TNF - $\alpha$ ligand compoundmaupun inhibitor reference) menggunakan Biovia Discovery Studio $)^{[6]}$. Hasil Biovia Discovery Studimenunjukkan adanya interaksi ligan dengan molekul target. Proses Analisa insilico dilakukan di Institut Bioinformatika Universitas Brawijaya Malang.

Data yang dihasilkan dari analisa molecular docking akan menunjukkan potensi masing-masing bahan aktif sebagai analgesik dan antiinflamasi. Analisa data menggunakan pendekatan melakukan perbandingan potensi masingmasing bahan aktif sebagai analgesik dan antiinflamasi. Penarikan kesimpulan berdasarkan hasil molecular docking bahwa suatu bahan aktif mempunyai potensi sebgai analgesik dan antiinflamais yang tinggi bila mempunyai nilai energi ikatan bebasnya lebih rendah dibandingkan inhibitor reference, dan semakin banyak asam amino yang terikat melalui ikatan hidrogen yang sama dengan inhibitor reference.

\section{HASIL DAN PEMBAHASAN}

Bahan-bahan aktif dari minyak atsiri daun Annona muricata melalui molecular docking menunjukkan aktivitas yang lemah pada semua molekul target. Hanya $\beta$-canidin yang menunjukkan afinitas cukup kuat pada COX-2 yang setara dengan indometachin 
(-8.1). Berbeda dengan bahan-bahan aktif pada ekstrak etanol daun Annona muricata yang menunjukkan afinitas yang tinggi pada molekul target COX-1, COX-2, sPLA, dan TNF- $\alpha$.

Bahan aktif dengan afinitas tinggi pada COX-1 melebihi dexamethason (8.8) dan indometachin (-7.7) yaitu cholorgenic acid (-9.0) dan rutin (-9.1). Bahan aktif dengan afinitas tinggi pada COX-2 melebihi dexamethason (-9.6) dan indometachin (-8.1) yaitu rutin (10.0) dan quercetin (-9.7). Bahan aktif dengan afinitas tinggi pada sPLA

Tabel 1. Analisis potensi inhibisi senyawa aktif ekstrak minyak atsiri dari daun Annona muricata denganreseptor

\begin{tabular}{|c|c|c|c|c|c|}
\hline \multirow[t]{2}{*}{ No. } & \multirow[t]{2}{*}{ Senyawa aktif } & \multicolumn{4}{|c|}{ Binding affinity dengan reseptor $(\mathrm{kcal} / \mathrm{mol})$} \\
\hline & & COX 1 & COX 2 & SPLA & TNF- $\alpha$ \\
\hline 1. & $\beta$-Elemene & -7.2 & -7.1 & -4.9 & -6.3 \\
\hline 2. & Linolol & -5.6 & -5.6 & -4.1 & -4.8 \\
\hline 3. & $\beta$-cadinin & -7.5 & -8.1 & -5.3 & -6.9 \\
\hline 4. & $\beta$-carryopilen & -6.5 & -6.6 & -5.6 & -7 \\
\hline 5. & eugenol & -6.6 & -6.1 & -5 & -5.5 \\
\hline 6. & $\alpha$-phinene & -5.1 & -6.2 & -4.1 & -5.1 \\
\hline 7. & germacrane & -6.2 & -6.1 & -4.9 & -6.3 \\
\hline 8. & $\begin{array}{l}\text { Indomethacin } \\
\text { (kontrol) }\end{array}$ & -7.7 & -8.1 & -5.8 & -6.4 \\
\hline 9. & $\begin{array}{l}\text { Dexametasone } \\
\text { (kontrol) }\end{array}$ & -8.8 & -9.6 & -5.8 & -9.7 \\
\hline
\end{tabular}

Tabel 2. Analisis potensi inhibisi senyawa aktif etanol dari daun Annona muricata denganreseptor

\begin{tabular}{clllll}
\hline No. & Senyawa aktif & \multicolumn{4}{c}{ Binding affinity dengan molekul target (kcal/mol) } \\
& & COX 1 & COX 2 & SPLA & TNF- $\alpha$ \\
\hline 1. & Catechin & -8.5 & -9.4 & -6.4 & -9.1 \\
2. & Chlorogenic acid & -9.0 & -8.3 & -6.0 & -9.3 \\
3. & Gallic acid & -6.4 & -6.5 & -5.1 & -7.0 \\
4. & Kaempferol & -8.4 & -7.7 & -6.2 & -9.1 \\
5. & Loliolide & -6.5 & -6.5 & -5.0 & -6.7 \\
6. & Rutin & -9.1 & -10 & -6.6 & -9.1 \\
7. & Quercetin & -8.6 & -9.7 & -6.4 & -9.1 \\
\hline
\end{tabular}




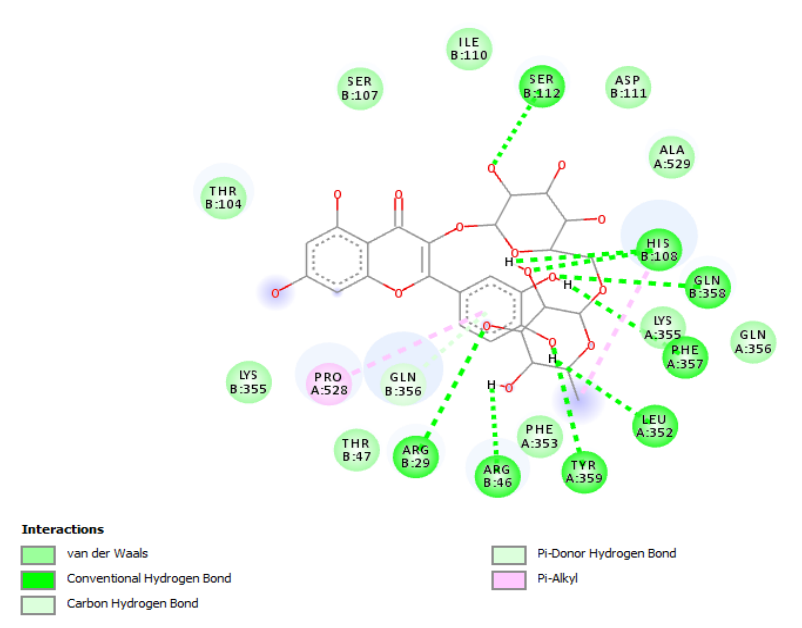

Gambar 1 Interaksi ligan antara quercetin dengan dengan reseptor COX-2 dengan metode in silico

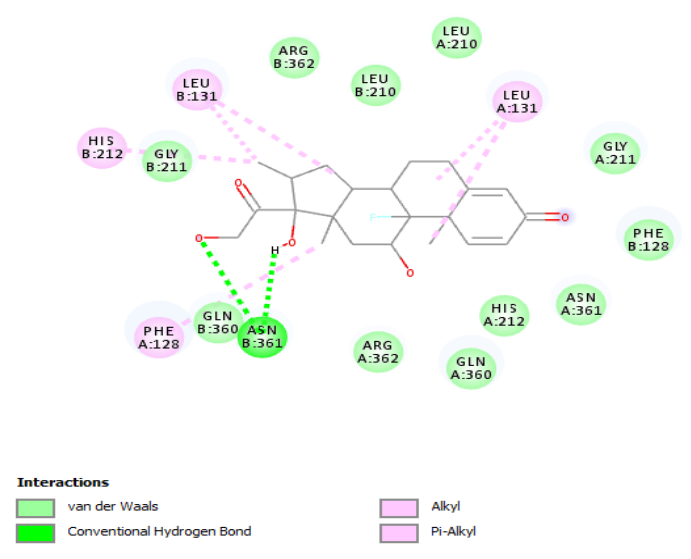

Gambar 2 Interaksi ligan antara dexametason (kontrol) dengan dengan reseptor COX-2 dengan metode in silico

Daun Annona muricata telah banyak digunakan secara empirik sebagai antiinflamasi dan analgetik ${ }^{[3]}$. Melalui studi in silico dengan metode molecular docking dapat dilihat beberapa bahan aktif ekstrak etanol daun Annona muricata memiliki tingkat afinitas lebih tinggi dari obat yang sudah ada (dexamethason dan indometachin). Nilainilai afinitas yang didapat dapat diduga bahan aktif yang paling berperan adalah rutin dan quercetin yang tampak kuat bekerja pada COX-1, COX-2, dan sPLA. Bahan-bahan aktif pada minyak atsiri memiliki afinitas yang tidak terlalu tinggi menunjukkan bahan-bahan aktif pada minyak atsiri tidak dapat digunakan sebagai antiinflamasi dan analgetik.

Analisis interaksi ligan (rutin) dengan reseptor COX 2 memiliki banyak interaksi ikatan hidrogen yakni pada residu asam amino Arg 29; Arg 46; His 108; Ser 112; Leu 352; Phe 357; Gln 358; dan Tyr 359. Melalui interaksi ikatan hidrogen ini yang diduga menyebabkan kestabilan inhibisi antara ligan (rutin) dengan reseptor COX 2 lebih stabil dibandingkan dengan dexametason (kontrol). 


\section{KESIMPULAN}

Ekstrak etanol dari Annona muricata memiliki potensi sebagai calon herbal terstandar. Hal ini diprediksi melalui docking memiliki daya hambat pada COX2 lebih kuat dibandingdengan dexametason dan indometachin sebagai standardnya.

\section{DAFTAR PUSTAKA}

[1] Dallakyan S, Olson AJ..SmallMolecule Library Screening by Docking with PyRx, Methods Mol Biol. 2015; 1263:243-50

[2] Delano W. L. The PyMOL Molecular Graphics $\quad 2000$. http://www.pymol.org

[3] de SousaO. V, G. D. Vieira, J. J. R. G. de Pinho, C. H.Yamamoto, and M. S.Alves. Antinociceptive and Anti-Inflammatory Activities of the Ethanol Extract of Annona muricata L. Leaves in Animal Models, International Journals Molecular Sciences. 2010. Vol. 11(5): 2067-2078.

[4] Perdo HL. A systematic review on CADD: Docking and Scoring, JMPI., 2010. p. 47-51.
[5] Wadood A, Ahmed N, Shah L, Ahmad A, Hassan H, Shams S. Insilico drug design: An approach which revolutionarised the drug discovery process. OA Drug Design \& Delivery. 2011. Vol. 01;1(1):3.

[6] Wallace, R. A. Laskowski, J. M. Thornton. LIGPLOT:a program to generate -schematic diagrams of protein-ligand interactions. Protein engineering. 1995 Vol. 8, No. 2., pp.

$127-$

134, doi:10.1093/protein/8.2.127

[7] Damayanti, D.S., Didik, D., Kusuma, C. Revealing the potency of Anona muricata leaves extract as FOXO 1 inhibitor for diabetes mellitus treatment through computational study. Silico Pharmacol. 2017; 1-7. 